\title{
Angiotensin converting enzyme and endotoxin induced lung damage in the mouse
}

\author{
WOCM COOKSON, MS WISEMAN, DJ SHALE \\ From the Osler Chest Unit, Churchill Hospital, Oxford
}

\begin{abstract}
Acute pulmonary oedema can be induced by intraperitoneal injection of Escherichia coli endotoxin in the mouse. A fall in serum angiotensin converting enzyme activity is found in mice given endotoxin and in patients with septic adult respiratory distress syndrome, and has been proposed as an indicator of lung microvascular injury. Protein concentration and angiotensin converting enzyme activity in serum, lung, and bronchoalveolar lavage fluid were determined in male mice up to eight hours after injection of endotoxin. By six hours the serum protein concentration had increased and the bronchoalveolar lavage fluid protein concentration had fallen, suggesting fluid shift into the lung. Angiotensin converting enzyme activity fell in serum and lung but increased in bronchoalveolar lavage fluid. As these changes in enzyme activity were not paralleled by changes in protein concentration they are unlikely to be a result of fluid shift or protein leak, and may indicate an active role of the enzyme in the response to sepsis.
\end{abstract}

Angiotensin converting enzyme is a glycoprotein with various biological activities. It catalyses the conversion of angiotensin I to the vasopressor octapeptide angiotensin $\mathrm{II}^{12}$ and mediates the destruction of bradykinin. ${ }^{3}$

Angiotensin converting enzyme is concentrated on the luminal surface of pulmonary endothelial cells ${ }^{2}$ and its serum activity has been shown to alter in chronic and in acute pulmonary disease.' A fall has been found in patients with the adult respiratory distress syndrome $\mathrm{e}^{4}$ and in mice with endotoxin induced pulmonary oedema. ${ }^{6}$ Because of these findings it has been suggested that serum angiotensin converting enzyme be used as a clinical indicator of the state of the pulmonary endothelium and pulmonary circulation in adult respiratory distress syndrome. ${ }^{1456}$ Previous studies have not provided evidence of microvascular injury other than a fall in serum angiotensin converting enzyme activity, which may, however, increase in other types of experimental acute pulmonary insult.$^{78}$ Little attention has been paid to any possible physiological role of the enzyme in these conditions.

This study aimed to define the distribution of angiotensin converting enzyme activity after pulmo-

Address for reprint requests: Dr WOCM Cookson, Osler Chest Unit, Churchill Hospital, Oxford OX3 7LJ.

Accepted 10 April 1985 nary damage induced in the mouse by Escherichia coli endotoxin. Protein concentrations in lung, bronchoalveolar lavage fluid, and serum were used as indicators of fluid shift and capillary permeability and were compared with changes in the enzyme activity in these compartments.

\section{Methods}

The experiment was carried out on 48 male mice (Parkes strain, Medical Research Council) of mean (SD) body weight $41.6(5.5) \mathrm{g}$. Ten control animals were given $2.5 \mathrm{ml} / \mathrm{kg}$ normal saline intraperitoneally. The remainder were given $E$ coli endotoxin (serotype $0111: \mathrm{B} 4$, Sigma) $0.5 \mathrm{mg} / \mathrm{kg}$ intraperitoneally and were studied in groups of nine or 10 two, four, six, and eight hours after injection. There was no difference in mean body weight between any of the groups.

Specimens were obtained under pentobarbitone anaesthesia (May and Baker, $120 \mathrm{mg} / \mathrm{kg}$ intraperitoneally). The abdomen was opened and $1 \mathrm{ml}$ of blood was taken from the inferior vena cava and allowed to clot on ice. Three millilitres of cold bicarbonate buffered normal saline $(\mathrm{pH} 7.4)$ were then injected into this vessel to clear the pulmonary circulation. The clotted blood was centrifuged at $500 \mathrm{~g}$ for 15 minutes and the serum decanted and stored at $-15^{\circ} \mathrm{C}$. 

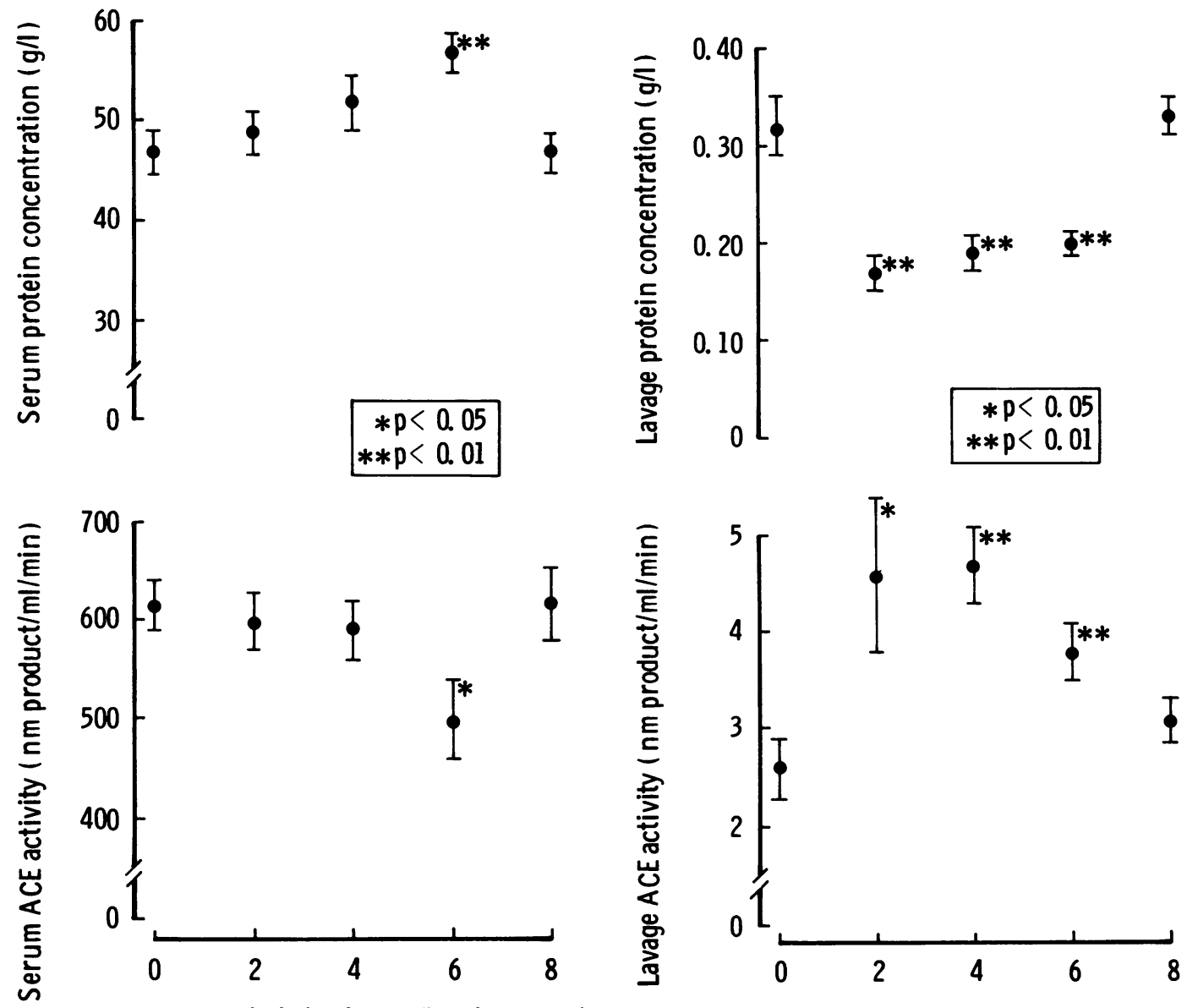

Hours after ip injection of $E$ coli endotoxin

Fig 1 Changes in serum angiotensin converting enzyme (ACE) activity and protein concentration after administration of endotoxin to mice. Results are mean values with standard errors shown by bars.

The trachea was exposed and the lungs were lavaged for 30 seconds with $2 \mathrm{ml}$ of bicarbonate buffered saline. The volume of fluid recovered from the lavage was recorded. The lungs were then removed and blotted dry before storage at $-15^{\circ} \mathrm{C}$.

The lungs were allowed to thaw and their wet weights were recorded. Each pair of lungs was then minced with scissors and a weighed portion of each was heated at $60^{\circ} \mathrm{C}$ until a constant weight was obtained. The water content of the lungs was calculated from the loss of weight.

A $100 \mathrm{mg}$ sample of each pair of freshly minced lungs was homogenised in $2 \mathrm{ml}$ of cold phosphate buffer $\left(0.1 \mathrm{~mol} / 1 \mathrm{~K}_{2} \mathrm{HPO}_{4} ; 0.3 \mathrm{~mol} / 1 \mathrm{NaCl}, \mathrm{pH}\right.$ 8.3) with a ground glass tissue grinder. Each homogenate was centrifuged at $500 \mathrm{~g}$ for 30 minutes at $4^{\circ} \mathrm{C}$ and

Hours after ip injection of $E$ coli endotoxin

Fig 2 Changes in bronchoalveolar lavage fuid angiotensin converting enzyme (ACE) activity and protein concentration after administration of endotoxin to mice. Results are mean values with standard errors shown by bars.

the supernatants were taken for angiotensin converting enzyme and protein estimations. The protein concentration was determined in lavage fluid, serum and lung homogenates by a colorimetric assay (Biorad Ltd, UK) with bovine serum albumin as a standard.9 Angiotensin converting enzyme activity was determined spectrofluorometrically with hippuryl-L-histidyl-L-leucine as the substrate (CBC Ltd) by the method of Friedland and Silverstein. ${ }^{10}$

Statistical analysis of the results was carried out with Student's $t$ tests. ${ }^{112}$

\section{Results}

Serum angiotensin converting enzyme was significantly lower than control values in the mice 
Table 1 Mean (SEM) lung weights and volumes of recovered bronchoalveolar lavage (BAL) fuid

\begin{tabular}{lccccc}
\hline & Controls & \multicolumn{4}{l}{ Mice given endotoxin: time (h) after injection } \\
\cline { 3 - 6 } & & 2 & 4 & 6 & 8 \\
\hline Wet lung weight (mg) & $277(7)$ & $274(13)$ & $286(13)$ & $291(19)$ & $284(14)$ \\
Dry lung weight (mg) & $40(1.0)$ & $38(2.0)$ & $39(1.8)$ & $42(1.4)$ & $38(1.6)$ \\
Lung water content (mg) & $237(6)$ & $236(11)$ & $247(11)$ & $249(18)$ & $246(12)$ \\
Recovered BAL fluid (m) & $1.0(0.08)$ & $1.2(0.13)$ & $1.3(0.13)$ & $1.4^{*}(0.09)$ & $1.13(0.08)$ \\
\hline
\end{tabular}

${ }^{*} p=0.018$ for comparison with controls.

studied 6 hours after injection of endotoxin $(p=$ 0.030 ) (fig 1). Values were not different from those of controls by 8 hours. Serum protein concentrations were higher than control values in the mice studied 6 hours after injection $(p=0.003)$ but not different from control concentrations by 8 hours (fig 1 ).

The angiotensin converting enzyme activity in the bronchoalveolar lavage fluid was raised by two hours $(p=0.035)$ and remained raised at $4(p=$ $0.001)$ and at 6 hours $(p=0.011)$ before returning to normal by 8 hours (fig 2 ). The lavage protein levels had fallen by 2 hours after injection ( $p<$ $0.001)$ and remained low at $4(p=0.002)$ and at 6 hours $(p=0.003)$, before reverting to normal by 8 hours (fig 2). The volumes of fluid recovered from the lavage procedure were increased at 6 hours after injection $(\mathrm{p}=0.018)$ (table 1$)$, but the changes in enzyme activity and lavage protein concentration remained significant when the volume of lavage fluid recovered was taken into account.

The total lung angiotensin converting enzyme activity fell by 4 hours $(p=0.036)$ and remained low at 6 hours $(p=0.015)$ before returning towards control values by 8 hours after injection (table 2 ). Neither the wet nor the dry lung weights altered significantly (table 1). There was, however, a trend for the wet weights to increase up to 6 hours after injection, and small increases in lung water content may have been swamped by lavage fluid. The increase in the volume of fluid recovered from lung lavage (table 1) 6 hours after injection was consistent with a fluid leak into the alveolar space. The total lung protein and the protein concentration per mg of dry lung did not alter (table 2).

\section{Discussion}

$E$ coli endotoxin causes pulmonary oedema in laboratory animals by inducing capillary leakage of fluid. ${ }^{1314}$ Any fluid flux may have effects on three pulmonary compartments: the intravascular, the interstitial, and the alveolar. In this study only two compartments, the intravascular and the alveolar, have been examined. But alveolar fluid may be taken to represent interstitial fluid, albeit with some modification by alveolar epithelium.

The increase in serum protein concentrations and the decrease in lavage protein concentrations found after endotoxin administration in this study are likely to be due to a protein poor fluid shift into the interstitial and alveolar spaces of the lung, although some fluid loss into other sites is probable. This is consistent with an early fluid shift into the lung found after endotoxin shock in the sheep, when the interstitial compartment of the lung has been studied by cannulation of lymphatics. ${ }^{13}$ We have not studied the later phase of the reaction to sepsis, when protein shift may exceed fluid shift. ${ }^{13}$

The changes validate the use of this mouse model of septic pulmonary oedema, which is attractive because of its simplicity and its low cost. Histological confirmation of pulmonary changes is, however, desirable before the model can be fully accepted.

This study confirmed the previously reported reduction in serum angiotensin converting enzyme activity occurring in the first six hours after endotoxin injection. ${ }^{6}$ The effect is transient, with values returning to normal by 8 hours. As serum angiotensin converting enzyme increases after acute toxic pulmonary injury, ${ }^{78}$ this fall may indicate an adaptive response rather than, as has been suggested, a result of endothelial injury. ${ }^{4-6}$

Estimations of enzyme in lavage fluid showed an unexpected increase, despite a fall in the total lung angiotensin converting enzyme activity. These results are unlikely to be due to a passive leak of the

Table 2 Mean (SEM) lung angiotensin converting enzyme (ACE) activity and protein content

\begin{tabular}{lcccc}
\hline & Controls & \multicolumn{3}{l}{ Mice given endotoxin: time (h) after injection } \\
\cline { 2 - 5 } & & 2 & 4 & 6 \\
\hline $\begin{array}{l}\text { Total lung protein (mg) } \\
\text { (nmol product/min) }\end{array}$ & $14.8(0.7)$ & $13.0(0.7)$ & $12.2(0.8)$ & $15.0(0.9)$ \\
\hline
\end{tabular}

${ }^{*} p=0.037,{ }^{* *} p=0.015$ for comparison with controls. 
enzyme into the lavage fluid as the molecular weight of angiotensin converting enzyme (136 000 daltons) is greater than that of albumin (65000 daltons), which is the major component of protein measured by this assay system ${ }^{9}$; and capillary leakage after this type of endothelial damage remains selective. ${ }^{13}$ The enzyme activity found in the lavage fluid might also result from angiotensin converting enzyme like activity in inflammatory leucocytes. ${ }^{15}$ In a different set of experiments we have shown that angiotensin converting enzyme activity after centrifugation of lavage fluid remains in the supernatant, and is minimal in resuspensions of the cellular precipitate (unpublished observations). The changes therefore suggest an active release, manufacture, or transport of the enzyme into or in the lung interstitium. The fall in total activity of the enzyme in the lung is consistent with depletion of stored enzyme and subsequent synthesis.

The reasons for the partitioning of angiotensin converting enzyme activity between the alveolar space and the circulation are unknown. This enzyme is a highly active biological substance with an important role in the production of angiotensin II. It may be presumed to play a part in circulatory volume and blood pressure homeostasis after septic insult, but this does not explain its appearance in alveolar lavage fluid. Possibly it is a part of a local response to fluid shift. It is a potent inhibitor of bradykinin activity, ${ }^{3}$ and angiotensin converting enzyme like activity due to cathepsin $G$ may be found in neutrophils. ${ }^{15}$ The enzyme might therefore be expected to play some part, as yet undefined, in the inflammatory response.

Although serum angiotensin converting enzyme activity may rise or fall in various types of pulmonary disease the physiological bases for these changes are not known. The pulmonary concentration of the enzyme seems as important as the concentration of the circulating enzyme in the conversion of angiotensin $I$ in the intact animal. ${ }^{16-18}$ Once in the serum, the enzyme is desialated and destroyed by the liver. ${ }^{1920}$ Serum angiotensin converting enzyme activity may be the residue of an enzyme whose function is located elsewhere, as is the case with serum transaminases; alternatively it may represent partially deactivated enzyme, although the serum enzyme and the pulmonary enzyme do not seem to be different. ${ }^{2}$ Additionally, the serum activity is a balance between the rate of removal from the serum and the rate of release from the lung, both of which processes may be affected by sepsis.

This study has shown an as yet unexplained increase in angiotensin converting enzyme activity in the alveolar space after endotoxin adminstration that is not a result of simple protein diffusion or ffuid' shift. It seems likely that this enzyme acts as more than a passive marker of endothelial damage within the pulmonary circulation.

\section{References}

1 Hollinger MA. Serum angiotensin-converting enzyme. Status report on its diagnostic significance in pulmonary disease. Chest 1983;83:589-90.

2 Das M, Hartley JL, Soffers RL. Serum angiotensinconverting enzyme. Isolation and relationship to the pulmonary enzyme. J Biol Chem 1977;252:1316-9.

3 Soffers RL. Angiotensin-converting enzyme and the regulation of vasoactive peptides. Annu Rev Biochem 1976; 45:73-94.

4 Bedrossian CWM, Woo J, Miller WC, Cannon DC. Decreased angiotensin-converting enzyme in the adult respiratory distress syndrome. Am J Clin Pathol 1978;70:244-7.

5 Fourrier F, Chopin C, Wallaert B, et al. Angiotensinconverting enzyme in human adult respiratory distress syndrome. Chest 1983;83:593-7.

6 Hollinger MA. Effect of endotoxin on mouse serum angiotensin-converting enzyme. Am Rev Respir Dis 1983;127:756-7.

7 Shasby DM, Shasby SS, Bowman CM, et al. Angiotensin converting enzyme concentrations in the lung lavage of normal rabbits and rabbits treated with nitrogen mustard exposed to hyperoxia. Am Rev Respir Dis 1981;124:202-3.

8 Hollinger MA, Giri SN, Patwell S, Zuckerman JE, Gorin A, Parsons G. Effect of acute lung injury on angiotensin-converting enzyme in serum, lung lavage, and effusate. Am Rev Respir Dis 1980;121:373-6.

9 Bradford M. A rapid and sensitive method for the quantitation of microgram quantities of protein utilising the principle of protein-dye binding. Anal Biochem 1976;72: 248-54.

10 Friedland J, Silverstein E. A sensitive fluorometric assay for serum angiotensin converting enzyme. Am J Clin Pathol 1976;66:416.

11 Snedecor GW, Cochrane WG. Statistical methods. 6th ed. Iowa: Iowa State University Press, 1971:91-116.

12 MINITAB statistical program. Pennsylvania: Pennsylvania State University, 1981.

13 Brigham KL, Bowers RE, Haynes J. Increased sheep lung vascular permeability caused by Escherichia coli endotoxin. Circ Res 1979;45:292-7.

14 Snell JD, Ramsey LH. Pulmonary edema as a result of endotoxemia. Am J Physiol 1969;217:170-5.

15 Tonnensen MG, Klempner MS, Austen F, Wintroub BU. Identification of a human neutrophil angiotensin II generating protease as cathepsin G. J Clin Invest 1982; 69:25-30.

$16 \mathrm{Ng} \mathrm{KKF}$, Vane JR. Conversion of angiotensin I to angiotensin II. Nature 1967;216:726-6.

$17 \mathrm{Ng} \mathrm{KKF}$, Vane JR. Fate of angiotensin I in the circulation. Nature 1968;218:144-50.

18 Ryan JW, Ryan US, Schultz DR, Whittaker C, Chung A, Dorer RE. Subcellular localisation of pulmonary angiotensin converting enzyme (kinase II). Biochem J 1975; 146: 497-9.

19 Ashwell G, Morell AG. The role of surface carbohydrates in the hepatic recognition and transport of circulating glycoproteins. Adv Enzymol 1974;41:99-128.

20 Kaplan J. Polypeptide-binding membrane receptors: analysis and classification. Science 1981;212:14-20. 